\title{
Architecture and Perspective in the Illusory Spaces of Ferdinando Galli Bibiena
}

\author{
Alessandra Pagliano1
}

\begin{abstract}
Stage design is an articulated system of projective processes, whose aim is to create a purely visual emotion for the spectators when the curtain rises, disclosing that portion of space that is behind the actors. Setting up a scene is a very similar process to architectural planning, made of plans, sections and executive details of each element, in order to create a physical space but having the sole purpose of giving back a global image of itself, exactly coincident with the planned sketch. However, this design complexity is rarely highlighted by scholars, who end up commenting that the sketch is just like a perspective painted image, without reading the need for transposition into the physical space of the stage, that instead affects many compositional choices and exceptions, hidden in the apparent harmony of the general overall picture. In particular, we'll examine Ferdinando Galli Bibiena's treatise, L'architettura civile preparata su la geometria e ridotta alle prospettive (1711), which carefully describes the aforementioned stage design complexity.
\end{abstract}

The scenographer visually liberates the text and the story behind it, by creating a world in which the eyes see what the ears do not hear (Howard 2002, p. 45).

Alessandra Pagliano

pagliano@unina.it

1 Università degli Studi di Napoli Federico II, Neaples, Italy 


\section{From the Sketch to the Stage: Transcriptions of a Multi-dimensional Visual Suggestion}

Stage design is an articulated system of projective processes, whose aim is to create a purely visual emotion when the grand drape rises, disclosing the space behind the actors, framed by the proscenium, which separates the illusory space on the stage from the real one in the auditorium.

The starting point and the perfect synthesis of the design complexity is the sketch, a painted perspective image which is a full design concept that simulates the vision of spectators; it is a single meaningful image that harmoniously synthesizes the measured alchemy of illusory tricks adopted.

The space depth, the architectural massing, as well as the luminous effects, are directly designed in perspective in order to evaluate the illusory effect which the scene will offer to the viewer; in geometric terms, this appealing painted and, thus, two-dimensional image, is ideally placed along a liminal plane, a virtual separation between the reality in the auditorium and the fiction beyond the grand drape. We could imagine it as a transparent veil, framed by the proscenium, which delimits and crops the perspective image. Proscenium is the architectural translation of the painting frame that is a limit for the perspective space it surrounds, as the Renaissance painters have accustomed us. Architecture has been, in the centuries, the undisputed protagonist of the scenic space, the privileged subject of any empirical attempts, studies and researches aimed at codifying a precise geometric method, able to perform a graphic transcription between different dimensions of spaces, due to the adaptation of stereometric volumes to the bi-dimensional iconic plane.

In theatre, the perspective image of the sketch is not the final result, but it must be enriched by a last projective process, completely absent in pictorial art: upon reaching the reduction of the physical space to the perspective drawing, this twodimensional image must be again appropriately transposed into the physical space of the stage, so that the sketch coincides perfectly with the perspective representation of that visual space. However, the small depth available on the stage is not enough to give the illusion of the impressive distances imagined by the scenographers.

Consequently, since the 15 th century, the scenic perspective became the most experimentational field of relief perspective (a forced, solid perspective), that is a geometric application of the general method of the perspectiva artificialis for illusory purposes, and it responds to the need for the expansion of the limited depth on the stage (Figs. 1, 2).

The gradual perspective reductions in size of each object and the convergence towards the back of all the lines (and surfaces) which have to appear perpendicular to the proscenium, added to the similar physiological deformation due to vision, are able to give viewers the effect of a much greater scene depth, creating an ephemeral space of contained depth, but visually equivalent to the sketch.

The geometry of the scenic space obviously includes the luminous phenomena too. Light plays an essential role, not only to guarantee good vision from the 


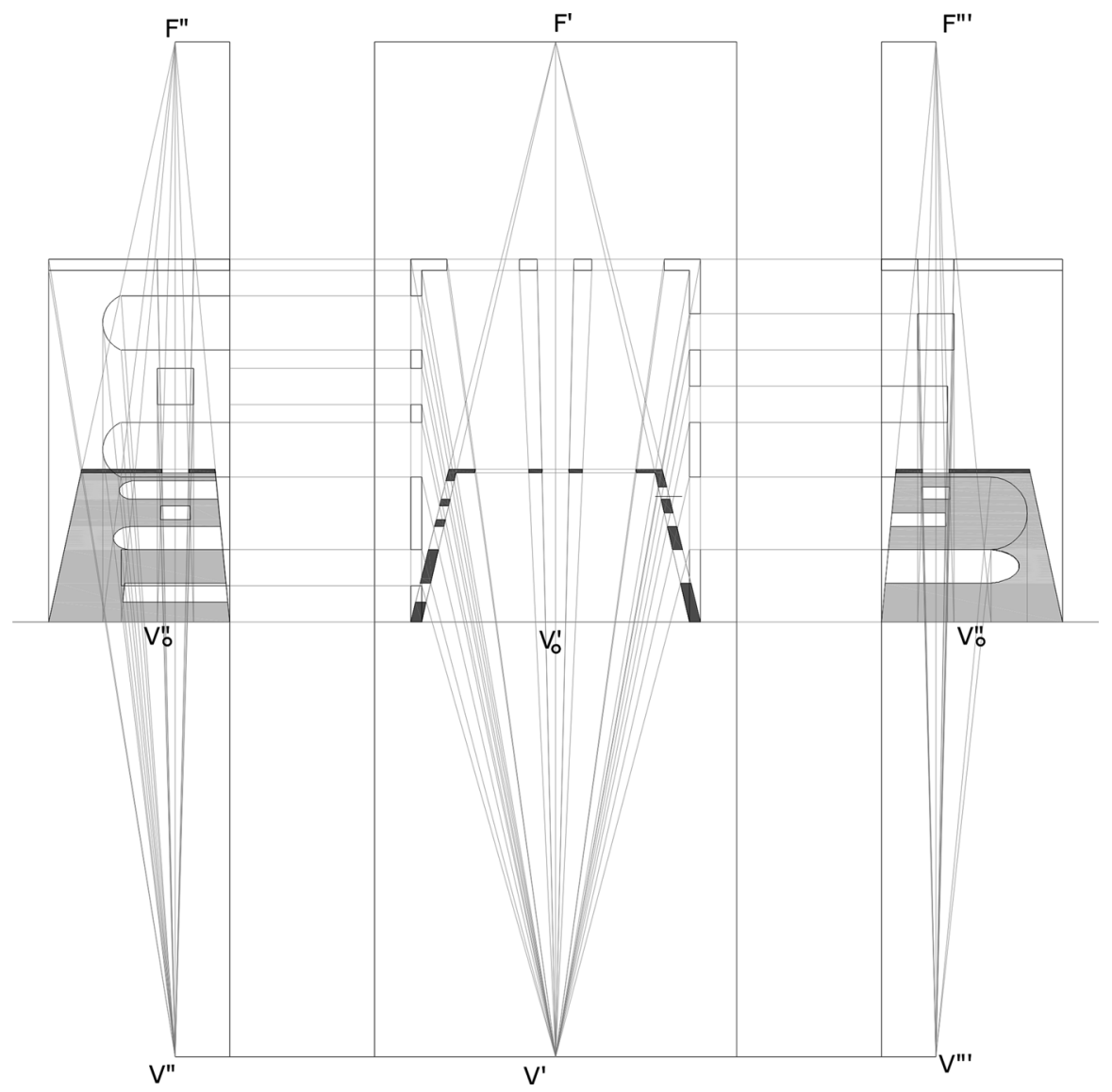

Fig. 1 Plan and cross sections of a generic forced perspective, compared to the real equivalent one

auditorium, but especially to offer a clear and immediate interpretation of the peculiar nature of the setting, because it contributes to create its expressive power.

But, as the structure of the theatre space originates from the pictorial space, the one and the other aiming to represent an ideal place, equally linked to the painting are the lighting effects in the theatrical scene that, before being applied on stage, are themselves designed and drawn in the perspective sketch.

As soon as the design of the sketch ends, the scenographer has to transfer that perspective image to the three dimensional physical space of the stage, which will provide a privileged observer (the point of view of the two-dimensional perspective of the sketch, and so, the centre of the whole projective process) a perceived image fully coincident with the painted one, which is imagined as a vertical transparent picture, placed in the frame of the proscenium. Figure 3 shows a brief history of some staging operations to set the sketch on the stage, about a successful opera setting, designed by Ezio Frigerio for Le Nozze di Figaro (1980), Teatro alla Scala in Milan. The starting point is the sketch, painted according to the perspective view of an observer sitting in the theatre's royal box; as in a circular path, the following 


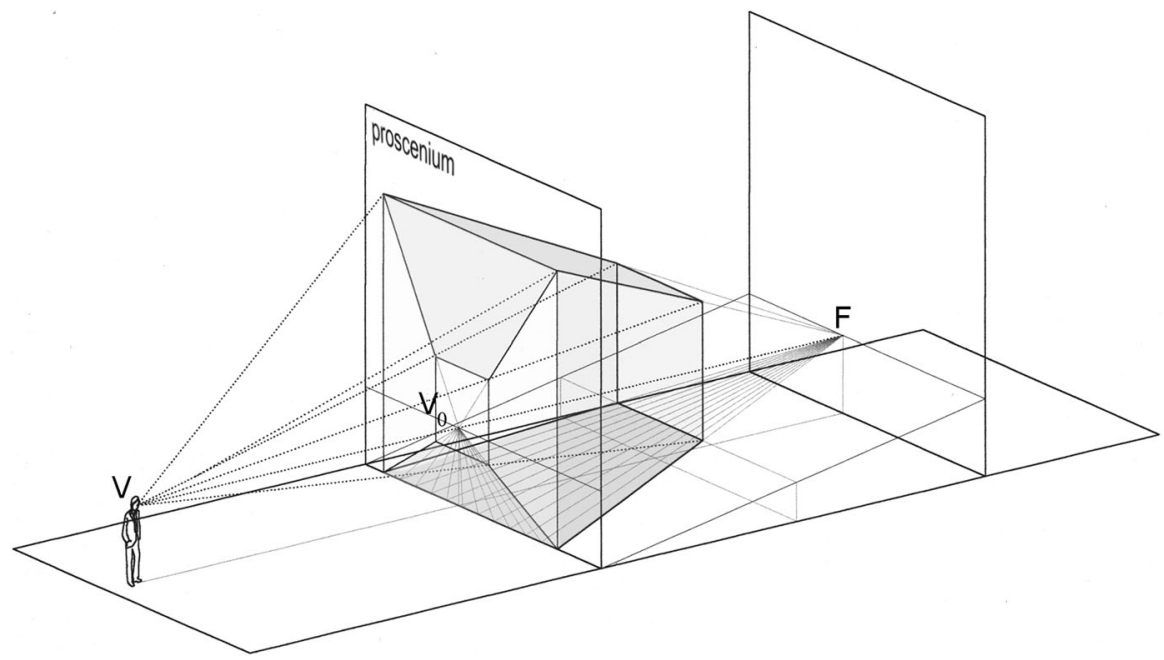

Fig. 2 The pyramid of planes in a generic forced perspective, to make the interior space appear deeper than it actually is
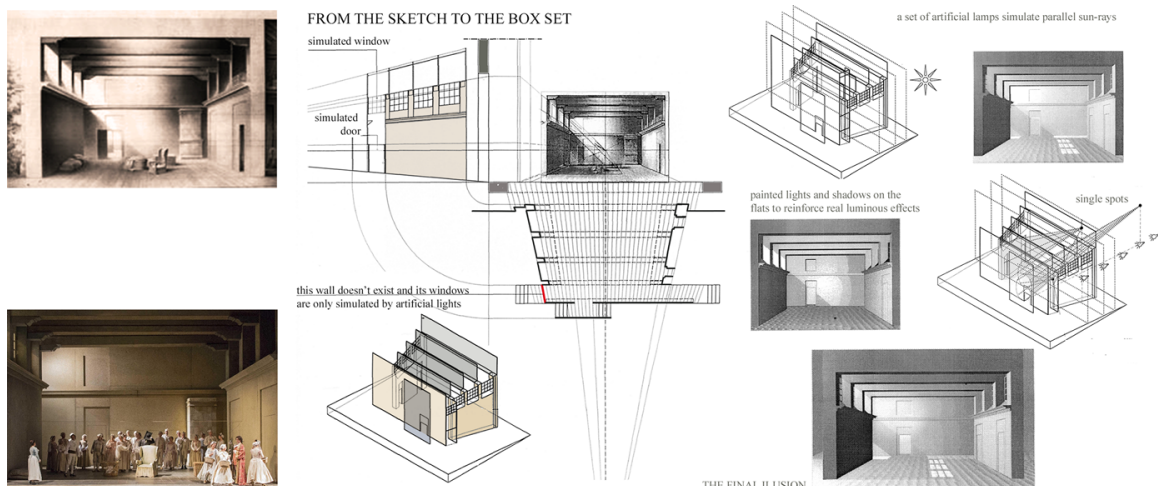

Fig. 3 Le Nozze di Figaro (1980), Teatro alla Scala in Milan, set design by Ezio Frigerio

steps aim to dispose flats, plastic volumes, shadows and lights in order to obtain an illusory forced perspective, fully coincident with the sketch.

Unfortunately, this design complexity is rarely highlighted by scholars, who critique the sketch just like a painted image, with chromatic, compositional and spatial values, sometime criticizing the architectural lexicon of the represented buildings, but without reading the underlying need for transposition into the physical space of the stage that instead affects many choices and exceptions, hidden in the apparent harmony of the general overall perspective. This lack is much more evident in the researches about those stage settings, produced before the invention of photography, which unfortunately are not documented by any evidence.

As an example, see the photos of a famous setting for Semiramide (1962), from the historical online archive of the Teatro alla Scala in Milan (Figs. 4, 5), that show 


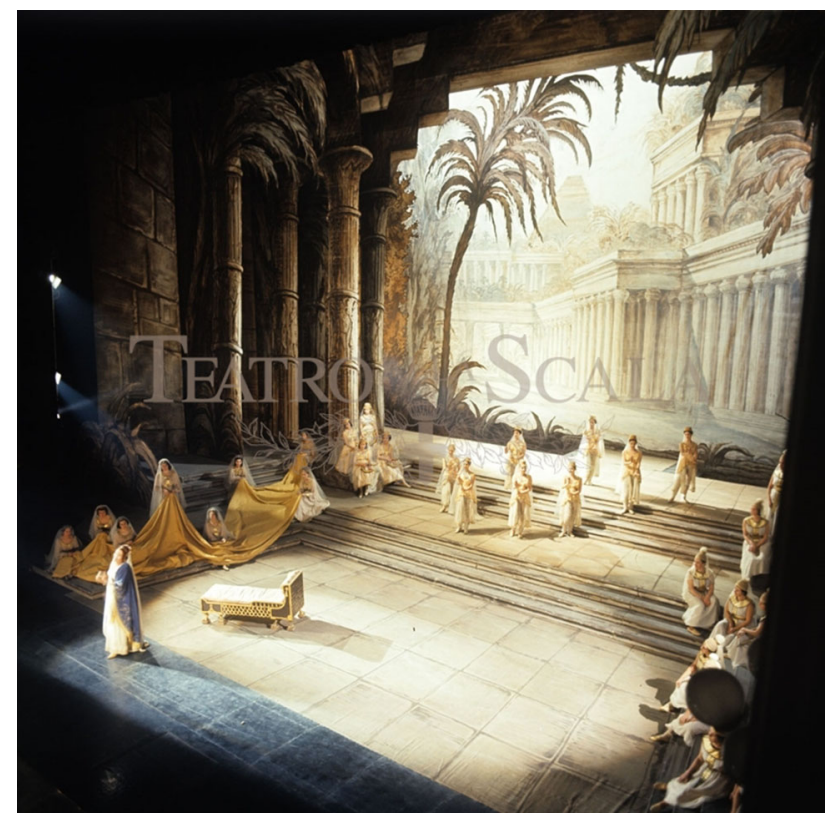

Fig. 4 Semiramide (1962), Teatro alla Scala in Milan, set design by Nicola Benois, based on old sketches by A. Sanquirico and F. Bagnara http://www.teatroallascala.org/archivio/risultato.aspx?lang=itIT\&uid=cb54a98a-8030-4e14-8443-01df48516393\&objecttype=base \&pagesize=9\&page $=1$

the measured alchemy of illusory tricks adopted on the stage, combining plastic statue and column in the foreground, with painted flats and backdrop in the depth; it is crystal clear that the columns are two-dimensional, but only for an observer within the stage and so for a point of view inaccessible to the public, who will perceive a plastic, three-dimensional illusion due to the well painted perspective when looking at the flat from the auditorium.

Recently, the major European opera houses have launched online historical archives, however, the Teatro alla Scala in Milan has no section fully dedicated to scenography while, in the archives of La Fenice in Venice, the sketches are catalogued together with the pictures and the theatrical posters; often, the name of the scenographer doesn't even appear. In the archive sections dedicated to the stage setting only appealing painted sketches and costumes are displayed, without any evidence referring to the spatial dimension, on the stage, of those images.

The present study aims to use a different point of view to analyze and study a scenic sketch, in order to highlight some derogations from the most usual perspective rules. These have to be considered as the consequence of an aware design, which doesn't stop at the painted image, but considers it as the starting point of some subsequent perspective tricks, in order to transpose the sketch to the physical space on the stage. We have therefore chosen, by way of example and by no way of limitation, the work of one of the greatest scenographers of the 18th century, Ferdinando Galli Bibiena, because he was a skilful designer and author of numerous papers and 


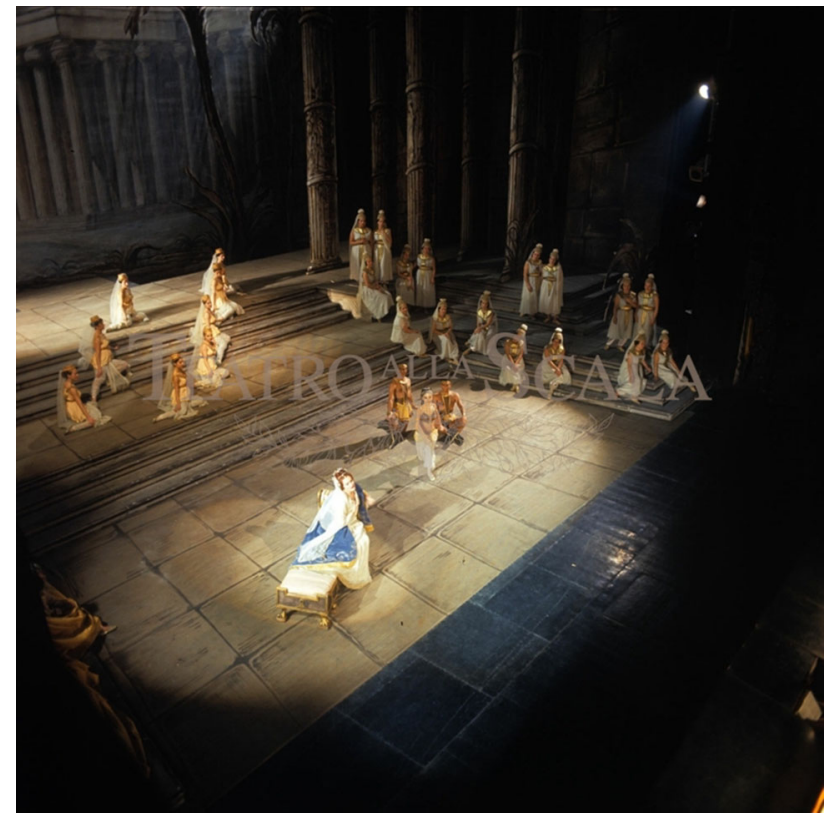

Fig. 5 Semiramide (1962), Teatro alla Scala in Milan, set design by Nicola Benois. The image shows columns painted on flats

treatises on architecture and scenography. He attributed his success to the invention of the so-called scena veduta per angolo, which marked, in the history of stage design, a significant innovation. His work influenced, for more than a century, a lot of future scenographers, but also several painters who, fascinated by the architectural perspective he invented, adopted the new style in their architectural fantasies, as shown by Piranesi's caprices The pier with a lamp (mid 1760s-early 1770s), from the Carceri d'Invenzioni, or by Juvarra's Cortile Reggio (1728-29). Perspective views that Ferdinando proposes as his own invention were a diffuse spatial experimentation among Baroque painters, but he had the merit to have been the first author to codify it in a treatise, referring the "scena veduta per angolo" to the field of painting as well as to stage settings (Fig. 6).

\section{Architecture and Perspective in the Treatise of Ferdinando Galli Bibiena}

The stage design complexity was carefully described by one of the greatest exponents of the Baroque theatre, Ferdinando Galli Bibiena (Bologna, 1657-1743). A versatile artist, architect and designer, he was the founder-member of a large family of European fame, in which three successive generations led to a significant turning point in the long-established layout of Renaissance scenography, introducing the dynamism and the spectacularity of the Baroque period. The first treatise 


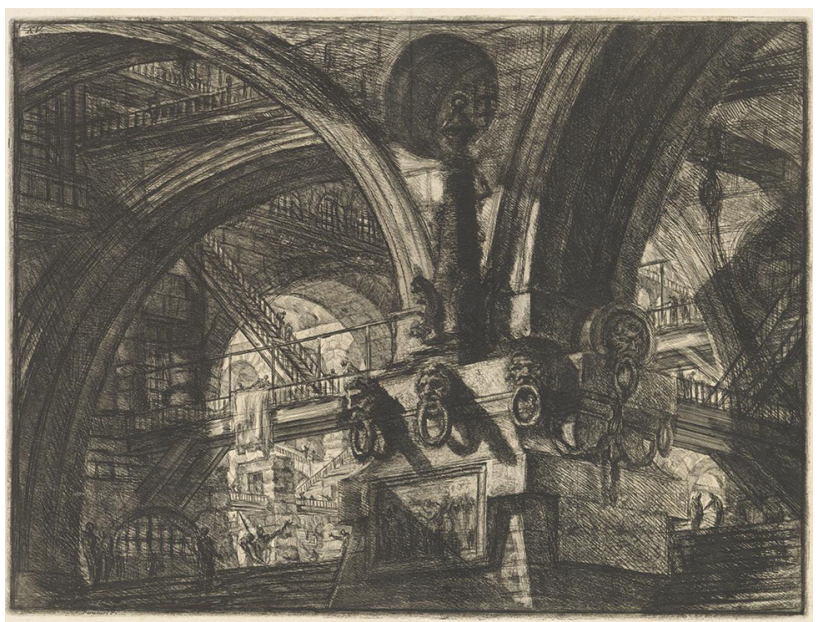

Fig. 6 G. B. Piranesi, The pier with a lamp (mid 1760s-early 1770s), plate XV from the Carceri d'Invenzioni (Imaginary Prisons) series (1761-late 1770s), 2nd edition, Rome

(Fig. 7) entitled L'architettura civile preparata su la geometria e ridotta alle prospettive (1711), is significantly divided into five distinct parts, according to the sequence considered by the author the most useful to train young students (to whom the work is dedicated), so that "... possa più agevolmente condurli alla pratica". The book is dedicated specifically to the training of a professional figure, strongly characterized by the practice, which does not belong to the category of scholars, but that, in any case, intends to differentiate himself from the amateur, thanks to knowledge learned by studying the treatise.

Bibiena's book is set up as a minimum necessary study plan, which aims to communicate to the student the fundamental bases of contemporary architectural culture, in order to make credible and consistent the buildings planned for the stage, if accompanied by the ability to draw in perspective a sketch characterized by suggestive expressiveness.

The first part is dedicated to Geometry, and to some indispensible warnings for the student "prima che à fabbricar si convenga", as in the frontispiece of Fig. 8, and it contains a large number of elementary geometric constructions, which the author estimates sufficient to measure any surface and body, both regular and irregular, letting the student to keep on studying the Authors mentioned in the beginning of the book in order to learn most accurate demonstrations, while he only aims to show practically what they need to work both in the field architecture, as in painting and sculpture (Fig. 8).

Starting from the fundamental geometric concepts, Ferdinando offers 75 constructions of regular plane figures, curves and solids, also teaching how to extract the metric data of area and perimeter, as well as providing the reader with a comprehensive and detailed overview of all the units of measurement most often used in the major European cities of that time. From construction no. 76, the treaty deals with stereometry, "ò misura de' corpi solidi", providing a guidance on how to derive metric data from even lesser known surfaces, as paraboloids and conoids. 


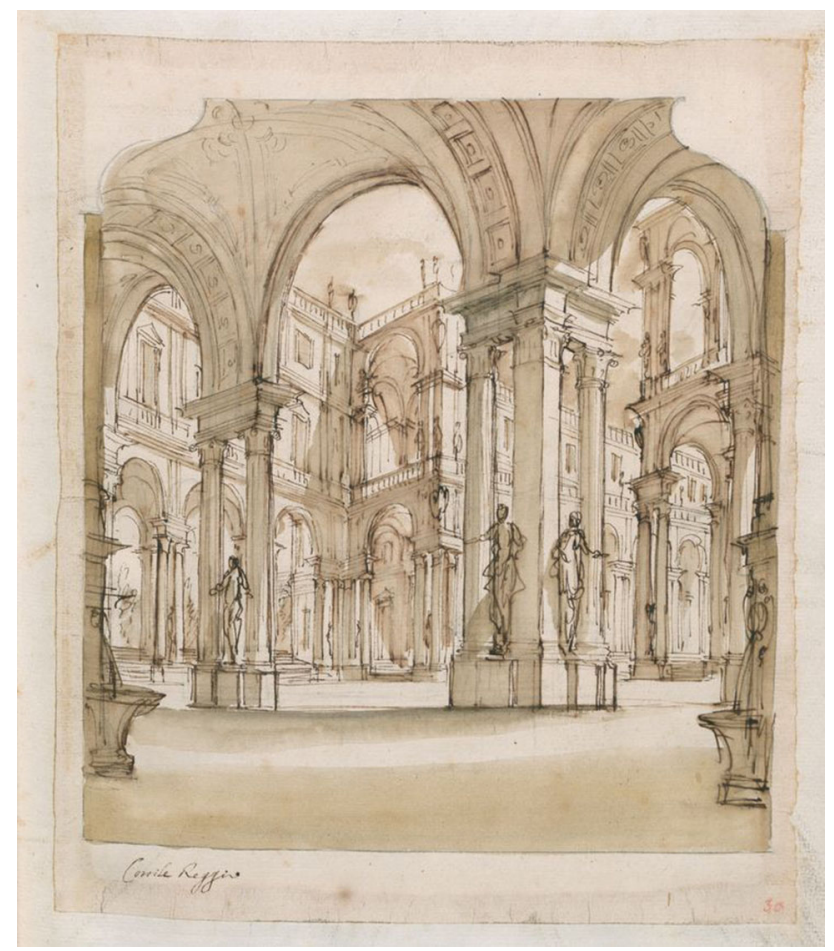

Fig. 7 F. Juvarra, Cortile Reggio, 1728-1729, Palazzo Madama, Turin

The first part ends with numerous warnings "before starting to build [prima, che à fabbricar si pervenga]", that is a large list, consisting of synthetic definitions, which appears as an admonition to the student to measure his own knowledge against the complexity of the issues, to encourage learning the basics, before working in the field of architecture.

Starting from the fundamental concepts of symmetry and eurythmy, we find the definitons of the main architecture elements and the technical drawings; then, the author comes to a classification of the most used building materials.

The second part, entitled "Brieve trattato dell'Architettura civile in generale", begins with the clarification that the arguments, although taken from the text of Vitruvius (Barbaro 1556), will be discussed with extreme synthesis, "with as much briefness as possible, explaining only what is really needfull [maggiore brevità sia possibile, toccando solamente quello, che è di necessità]" (Galli Bibiena 1711, p. 39).

The title L'architettura civile preparata su la geometria e ridotta a le prospettive articulates how the drawn architecture, rather than built, will mark the whole work: the geometry, which is the indispensable foundation of every technical drawing, constitutes the basis, while the architectural perspective is even the end. The practical target of the entire work seems to have to adapt itself to a professional figure, rather than an erudite scholar, thus prompting many 


\section{ARCHITETTURA CIVILE PREPARATA SU LA GEOMETRIA, E RIDOTTA ALLE PROSPETTIVE. CONSIDERAZIONI PRATICHE \\ D I \\ FERDINANDO GALLI BIBIENA \\ C I T T A D I N O B O L O G NESE \\ ARCHITETTO PRIMARIO, CAPO MASTRO MAGGIORE, E PITTORE DI CAMER A, E FESTE DI TEATRO DELLA MAESTA DI CARLO III. IL MONARCA DELL.E SPAGNE DISJEGNATE, E DESCRITTE IN CINQUE PARTI. \\ La prima contiene la Geometria, $\mathrm{e}$ av vertimenti, prima che à fabbricar fi pervenga. \\ La feconda. Un Trattato dell' Architettura civile in generale, e le divifioni di effia molto \\ La Terza. La Profpettiva commune, orizontale, e di fotto in sù. \\ La Quarta. Un brieve difcorfo di Pittura, e la Profpettiva per li Pittori di Figure, colla nuova Profpettiva delle Scene Teatrali vedute per angolo, oltre le praticate da tutti
gli altri. \\ La Quinta. La Mecanica, d arte di movere, reggere, e trafportar pefi.}

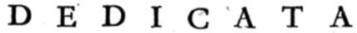

Alla Sacra Cattolica Real Maeftì

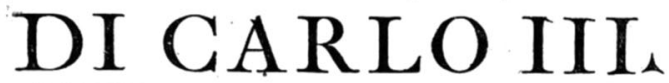

RE DELLE SPAGNE, D' UNGHERIA, BOEMIA \&c.

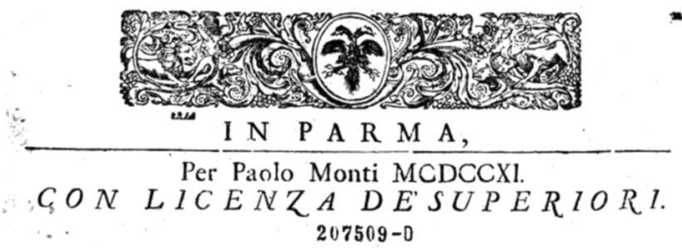

Fig. 8 Frontispiece of Ferdinando Galli Bibiena's treatise (1711)

researchers to affirm that the treatise is destined for the architectural perspective of the stage setting, from its very first pages, and therefore, to train young scenographers who want to consolidate their general preparation, to escape the mere practice of handicraft.

According to a well-established tradition, in the second part of the book, Ferdinando deals with the description of the five classical orders, although according to a simplified key of reading, and without the use of any mathematical formula. Notwithstanding the obvious citations of the great masters who preceded him, Vitruvius in particular, the creativity of the author emerges from the architectural drawings, as well as being explicitly stated when he says that "All moulding profiles that are in the book, with the exception of Vignola's ones, are of my personal invention, saving proportions, from which I didn't differ at all [Le Sagome di tutti li corniciamenti, che vi sono, fuori di quelli del Vignola, sono tutti di mia invenziona, fuorchè le proporzioni, dalle quali non mi sono quasi scostato 
niente]" (Galli Bibiena 1711, p. 45), however advising the reader to evaluate carefully, through the perspective drawing (suggested as the only efficient foreshadowing instrument in the first design phase) what the visual effect of the architectural mouldings from below will be, depending on their height and on the amplitude of the surrounding space, as well as the lights, from which they will be invested.

The third part is dedicated to linear perspective, with vertical, oblique and horizontal planes of projection, and it is the final and unavoidable destination of the entire book, because the author claims it as the essential knowledge that no artist or architect can avoid.

Ferdinando defines it as a deception of the eyes (Accolti 1625) but specifies that "there is not most important thing, to see in one single glance, the plan, the elevation, the inside, and the exterior of a building in a single drawing [... non vi è cosa più essenziale, per far vedere in un'occhiata sola, la pianta, l'alzata, il di dentro, e fuori delle fabbriche in un disegno]" (Galli Bibiena 1711, p. 77), thus emphasizing, according to a purely theatrical reading, the illusory effects of this geometric method and his will to teach how to create, directly according to a perspective view, a picture of the whole architectural ensemble, which also includes the shadowy and light effects, with a clear reference to the function of the theatrical sketch in the design process of the scene.

The Author cites frequently Ignazio Danti, Lorenzo Sirigatti and Vignola, explaining to the reader that all the perspective constructions he draws in the treatise are derived from other books, although the order in which they are proposed is the result of a precise and personal didactic choice.

It seems appropriate to note that, while the construction of flat geometrical figures and regular solids are conducted by using a plan below the ground line (Fig. 9), when the Author deals with the drawing of architectural elements, such as decorations, mouldings, columns and capitals, he proposes a method that starts from a second orthogonal projection, a prospect, from which he teaches how to draw the perspective depth through inclined lines of $45^{\circ}$, with respect to the picture plane, which coincide with the diagonals of the corner mouldings (Fig. 10).

The fourth part of the treatise contains numerous warnings, recommendations and admonitions to young students who want to approach painting but, of particular interest for the present study, are the latest "operations" in which Ferdinando Galli Bibiena describes how to draw human figures in landscape or in architectural scenes, by placing the characters directly along the depth of the perspective scenario, so that degradation of heights appears lifelike, because they conform to the reductions due to the perspective method (Fig. 11).

After dedicating a few pages to anamorphosis, described as strange perspectives from particularly angled points of sight, but without the recourse to any precise geometric definition, he illustrates how to draw cast shadows by sunlight and the artificial light of some chandeliers.

The treatise finally reaches the theoretical corpus of stage design, towards which Bibiena has trained students in the previous pages; we realize we are in the presence of the main theme of the whole work because the same author, previously very rigorous in attributing the authorship of any constructions proposed to scholars and 

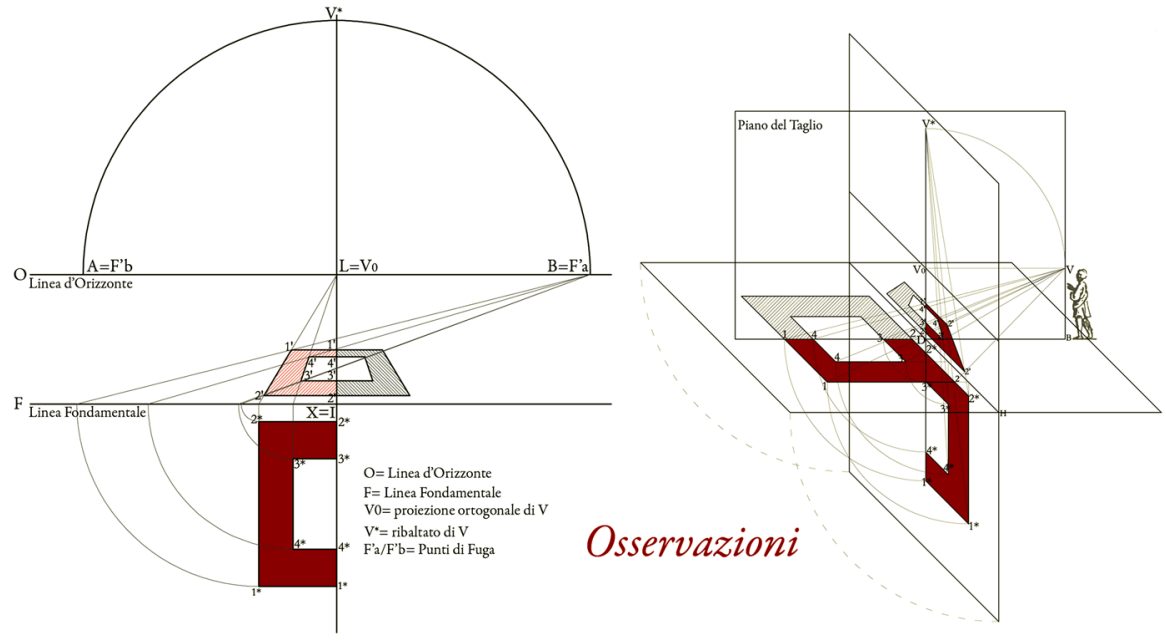

Fig. 9 Bibiena's geometric process to draw in perspective a square

researchers who had preceded him, does not hesitate in alerting the reader that all arguments, from now on are his own invention, because no one before has been able to provide clear rules for graphic-projective processes that allow a proper theatrical staging.

According to a practical method, based on a proportional system of decreasing heights and distances of the telari (flat painted panels), along the depth of the stage, the Author illustrates some graphic methods to define the point of the convergence, that is, the apex of the perspective pyramid, created on stage as a result of the relief perspective (Pagliano 2002): it's defined as "punto del finto in iscorcio, ò sfuggita". Ferdinando explains that this point could also be located outside the physical space of the stage, due to its nature as a simple geometric locus that regulates the convergence of each element in the forced perspective. Then he emphasizes the importance of planning the scene, from the beginning to the end, just according to a perspective drawing because, in this way, it will not be possible to act with the most common and practical methods of stagecrafting that use strings stretched, tied to the proscenium, because of the physical impossibility to make them converge towards his inaccessibile point. If Sebastiano Serlio (1545) had certainly the merit to have understood, for the first time, that the vanishing point of the relief perspective does not coincide with the principal point of the backdrop, but is located beyond the plan itself, it is even more confused, for most of the authors, the link between the principal point on the backdrop, and the point of sight, which coincides with the privileged position of the observer and is the unique centre of projection, that Ferdinando Galli Bibiena places at different heights, the latter up to the first floor boxes, where "... li Personaggi più riguardevoli ad ascoltare e vedere le Opere" are usually seated (Galli Bibiena 1711, p. 132).

Already Andrea Pozzo, in 1698, had clearly set the right alignment of the point of sight, the vanishing point on the backdrop and the apex of the solid accelerated 


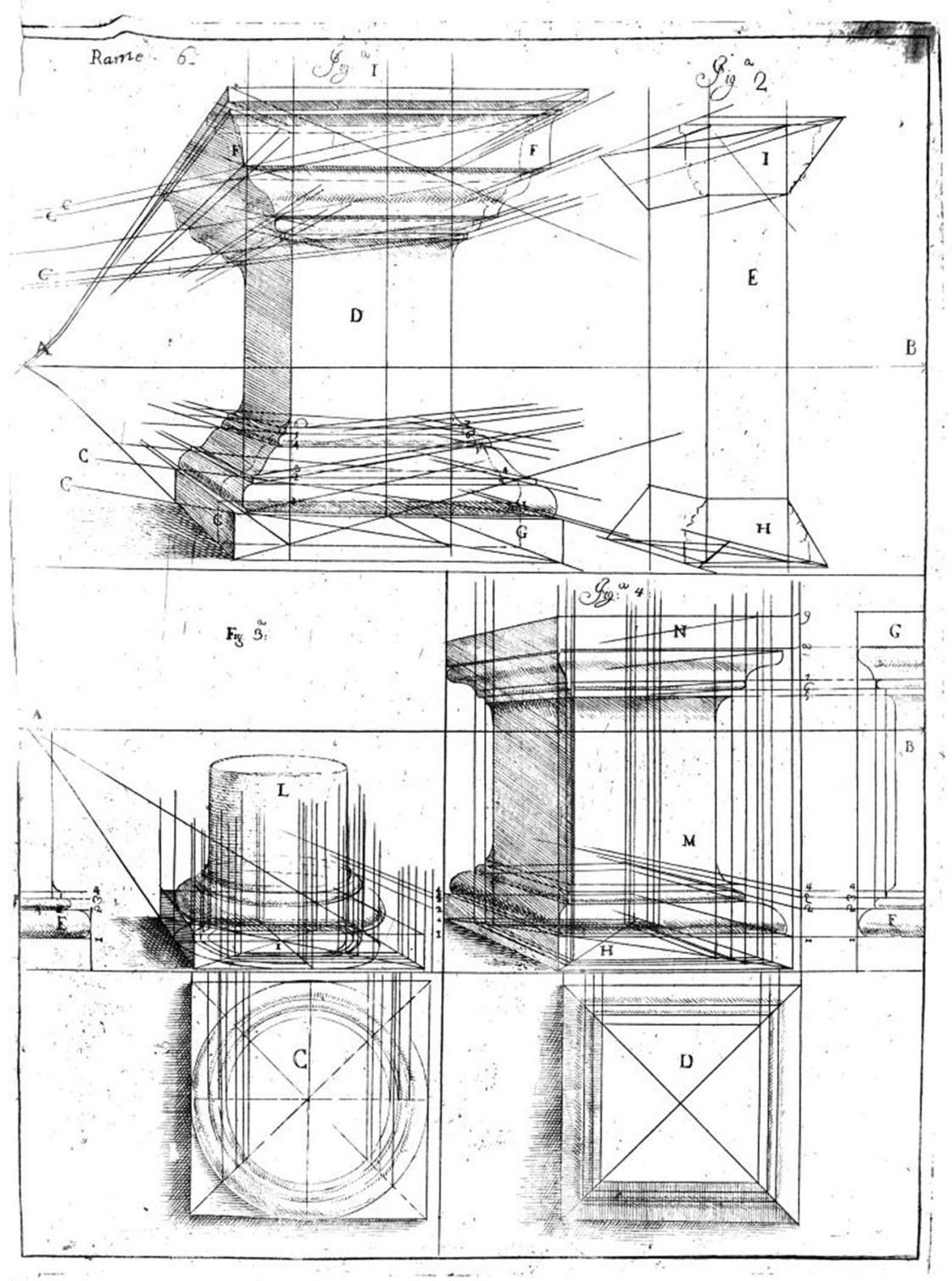

Digitalizzato da Google

Fig. 10 Ferdinando Galli Bibiena (1711). Per formare in prospettiva la mebratura delle cornice (Galli Bibiena 1711: 91) 


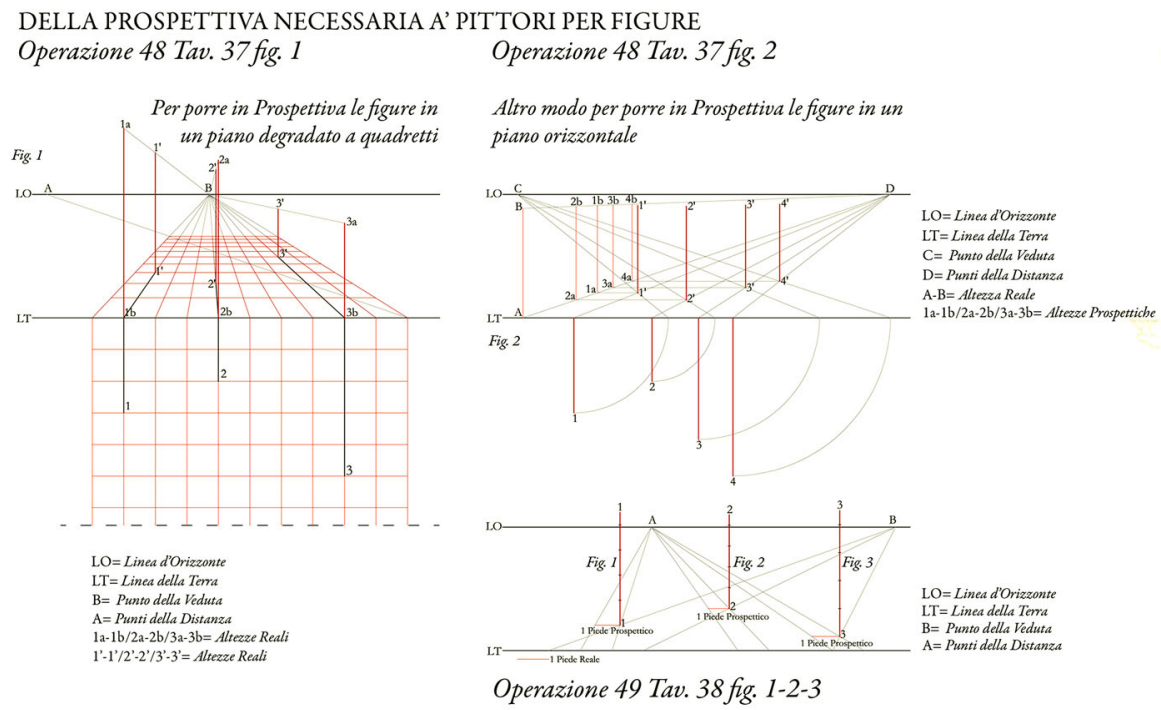

Fig. 11 Geometric method illustrated by Ferdinando Galli Bibiena to draw the heights in a perspective scenario

perspective along the same horizontal line, passing through the eye of the privileged observer.

According to a complex system of progressive hostings, between the container space and the graphic-narrative contents, as in a game of Chinese boxes between form and content, the flat panels' sizes are subjected to the forced perspective, which governs the entire three-dimensional space of the stage, but each of them becomes also the portion of the two-dimensional painted image and thus, each one of them possesses, in its own plane, one or more vanishing points of parallel straight lines, which have to harmonize their position with all the others vanishing points, and with the principal one on the backdrop (Fig. 12).

Then, the treatise shows how to create the famous angle perspective, defined as "vedute per angolo", which is the real innovation that Ferdinando Galli Bibiena introduces in the history of stage productions, and thanks to which the whole family gained a European reputation, working at the courts of the greatest kings of the time, for more than a century.

The setting is characterized by the accidental position of the main architectures with respect to the plane of the proscenium. Perspective image is developed starting from the corner of a building that has been brought forward. No longer is the façade of a building to appear in the foreground, but rather an edge, from which all lines branch towards two different vanishing points, which is a great difference if compared to the single central point of the Renaissance stage setting.

The strong evidence of the edge drives the spectator to slip with his eyes along the lateral façades, thus feeling free from the need to assume a central position. We can say that Ferdinando fully realized the scenic theories of Andrea Pozzo (1723), 


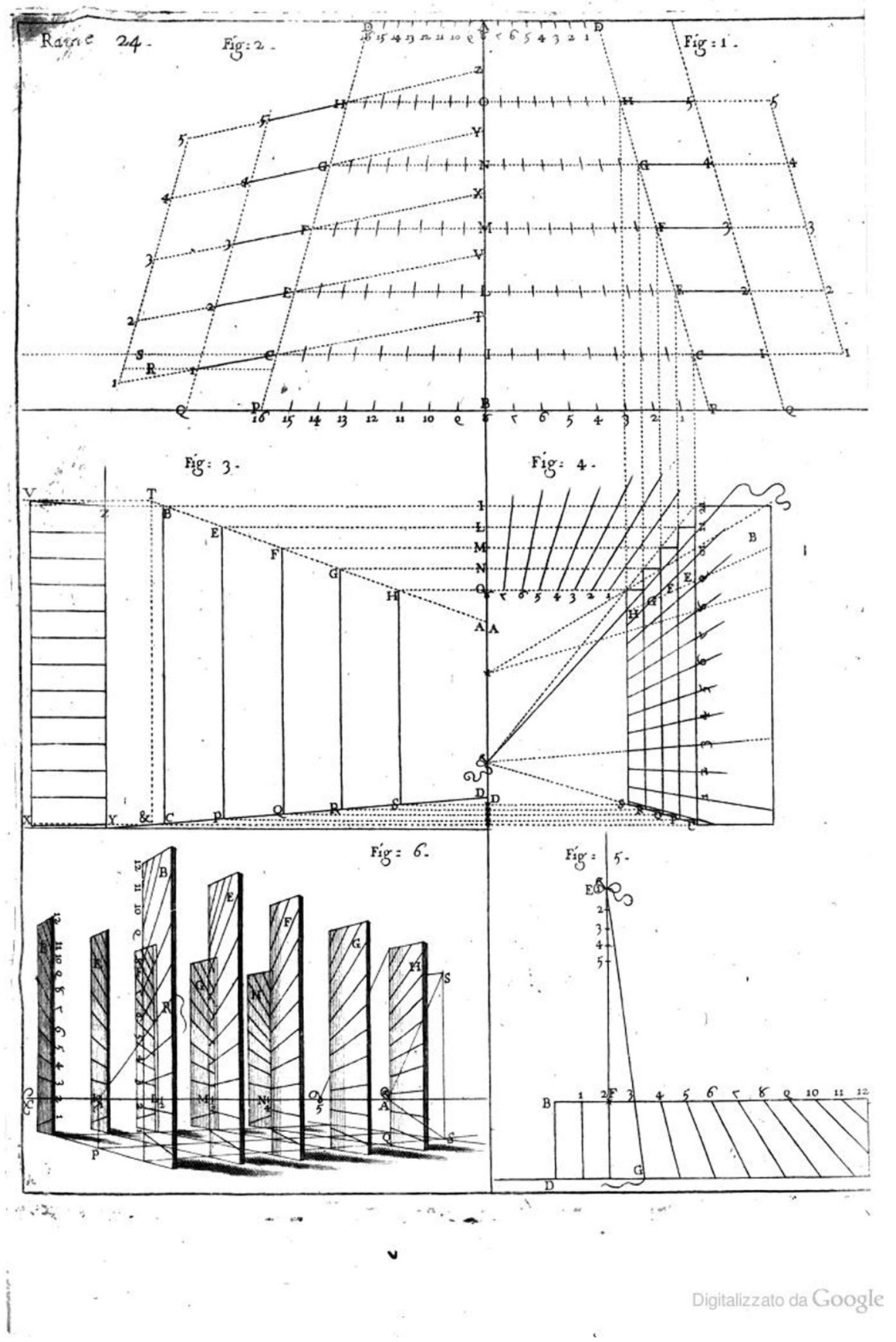

Fig. 12 Ferdinando Galli Bibiena (1711). Per disegnare le Scene nè Telari oblique, non paralleli alla fronte del palco (Galli Bibiena 1711, p. 139) 
creating a perspective system linked to the presence of a single centre of projection, to which the endless individual perspectives from the auditorium can overlap.

The Author warns the readers about the importance of starting with the design of the building, according to the architectural proportions and the most common geometric rules, in which the plan must be arranged below the ground line; following the constructions illustrated in the preceding pages, he then invites the reader to obtain the perspective plan. To draw the heights, Ferdinando instead places a significant portion of architecture on the right side of the drawing, translating all the heights towards the trace of the vertical plane, to which the architectural front is referred. To avoid the false interpretation that includes this front into the perspective scene, and in order to check its correct geometric link to the plan, we rotated the façade according to the plan inclination and highlighted in red some basic perspective constructions.

Also in this case, the deep knowledge of geometrical rules, combined with the desire to simplify the graphic processes, guided the Author to dispose the plan of four vertical corners of the building just in coincidence with the ground line, so that the heights are coincident with the iconic plane, in order to deduce, with a simple translation, the desired measures (Fig. 13).

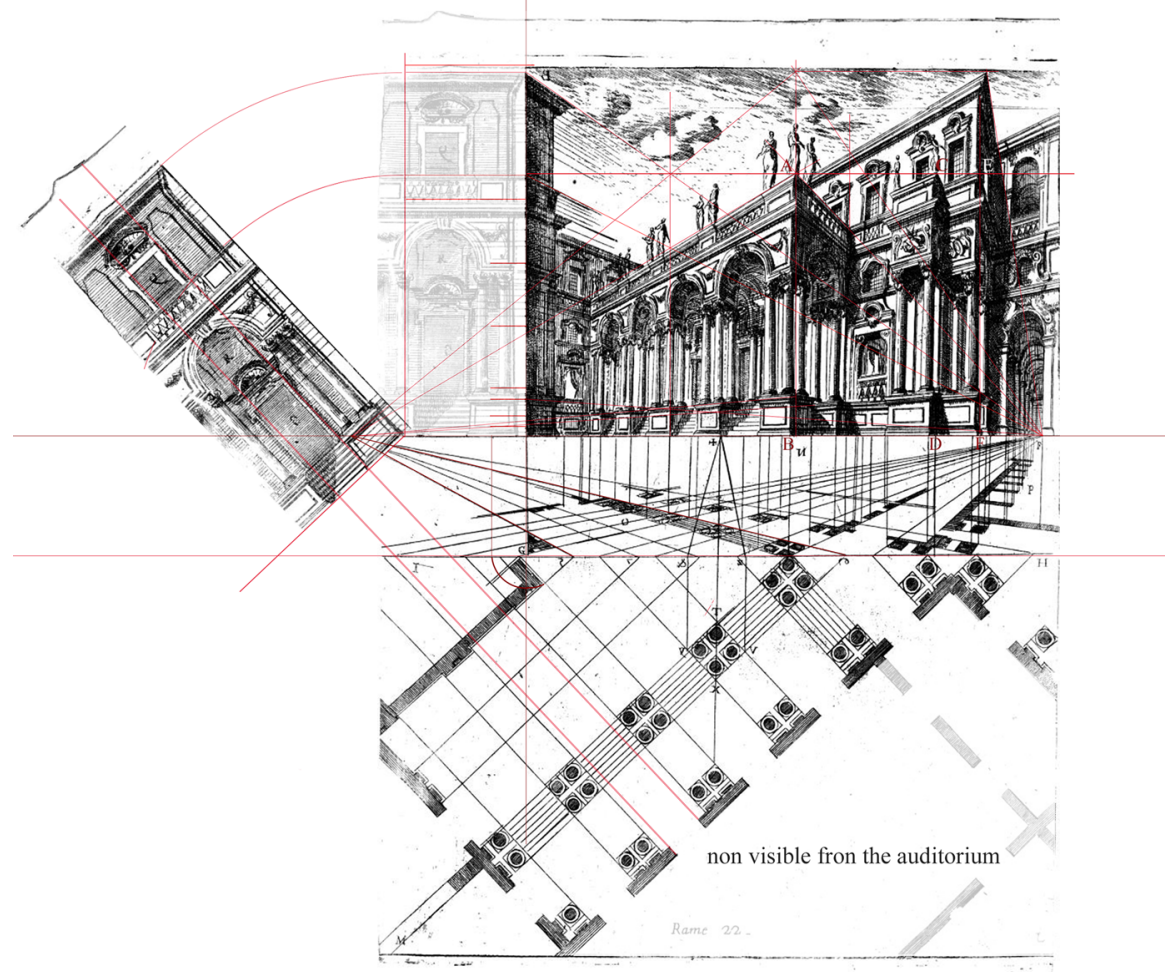

Fig. 13 Geometric processes involved in the Bibiena's drawing Per disegnare le Scene vedute per angolo, e prima di quelle d'un cortile (Galli Bibiena 1711 p. 135) 
The aforementioned architectural perspective becomes theatrical when Ferdinando, starting from the plan previously drawn, decides to put the ground line into a coincidence with the vanishing line of the horizontal plane. This geometric expedient allows the Author to draw the whole perspective plan as coincident with the straight line of the horizon, so that the image could be more easily painted along the flats on the stage, thus obtaining an effect of greater realism because the vertical lines are erected directly from the base of the painted panel. This perspective expedient is even more useful, for illusory purposes, if we refer it to the base of a circular column, where the perspective drawing turns into an elliptical form: having to dispose the image of the column along a vertical flat, the perfect coincidence between the base of the panel and the perspective plan, so reduced to a simple segment, allows the scenographer to give more realism to the inevitable contrast of lights at the intersection between the vertical panel and the floor of the stage, which should not therefore be deceptively extended along the panel (Fig. 14).

The rise of the ground line leads to a lowering of the point of view to the ground, so generating a suggestive image, characterized by great dynamism, if compared with the perspective of the same building as it would be perceived by an observer with the point of sight placed at the original horizon level (Fig. 15); the corner in the foreground is more prominent and it drive the observer to look towards the mouldings in the upper part of the building, that appear, that way, more monumental.

We can hypothesize that the described drawing is a first demonstration of his new monumental architectural perspective style, and not a theatrical sketch yet, because Ferdinando draws in plan some invisible interior walls, so contrasting one of the principal rules on the stage: what's invisible for all the audience does not exist (and it's useless to build it). It's important to note that Ferdinando exhorts students to transpose the architectural perspective on to the flat panels, laid out on the stage according to the rules described in the previous chapters.

However, observing the continuity of the perspective façade, it is difficult to understand how the Author could have imagined to isolate some slices of the image in order to be painted on several flats, considering their arrangement on stage still

Fig. 14 Generic perspective view to explain the method, used by the Author, to adapt and best fit the perspective of a column to the flats

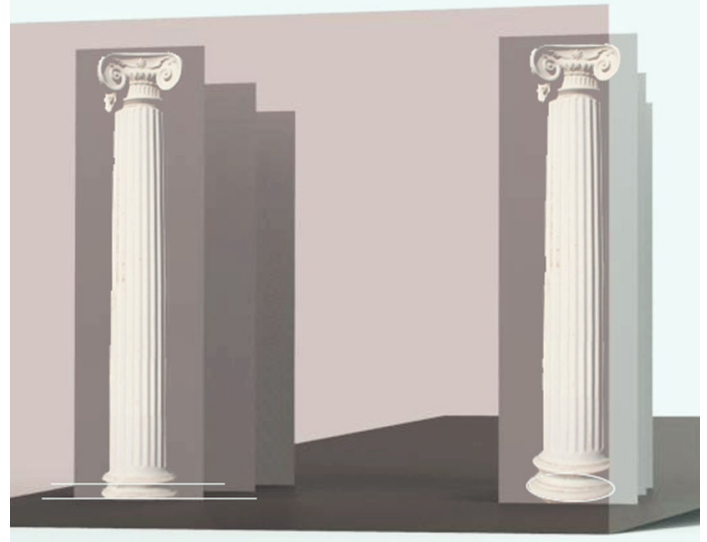




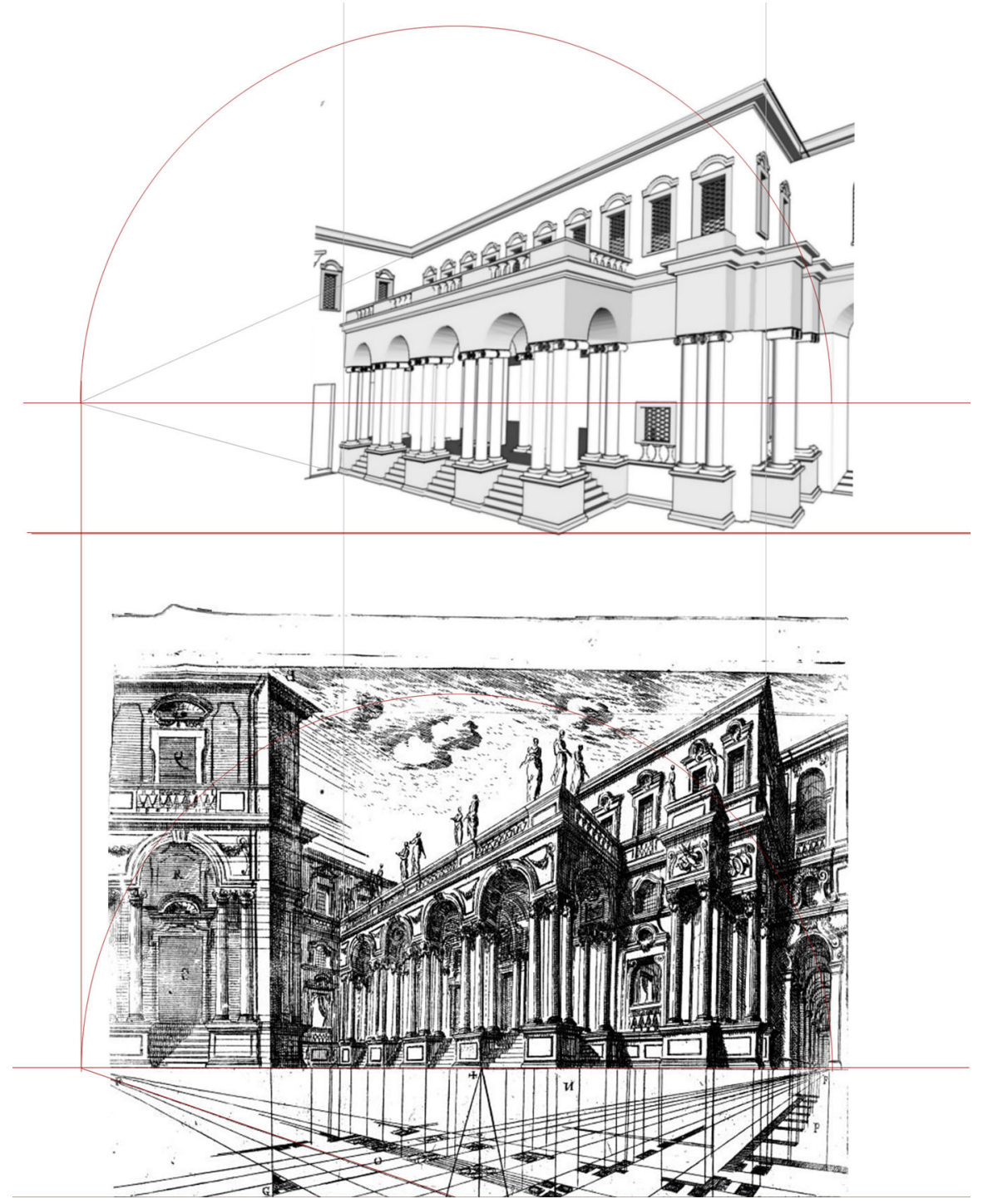

Fig. 15 Comparison between Bibiena's perspective images of the building and the correspondent one that the observer would perceive with the point of sight placed at the original horizon level

strongly influenced by a symmetrical layout of a Renaissance type, with the panels disposed on both sides of a central empty space.

Figure 16 shows the most likely stage setting of the perspective invented by Ferdinando Galli Bibiena, in which the painted backdrop is entrusted to host the most part of the drawn architecture, while the first flat is painted according to the short perspective view of the building in the foreground. 


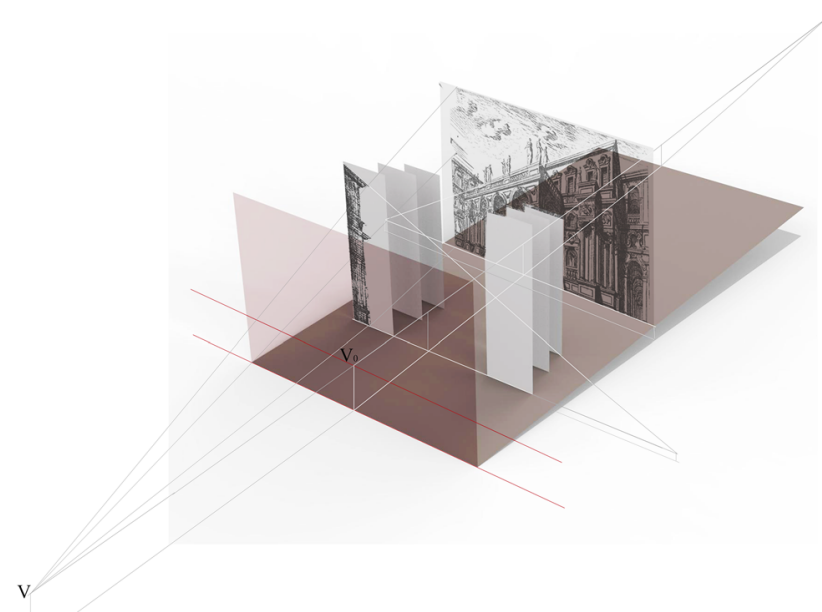

Fig. 16 A likely stage setting of the first scena veduta per angolo invented by Ferdinando Galli Bibiena

This architectural perspective, therefore, can be interpreted as the "manifesto" of a new style, in terms of painted views, rather than a theatrical sketch because it is lacking in the practical realization that instead Bibiena emphasises constantly in his treatise.

We find a similar process in operation no. 68 , immediately after, that shows a square transept, covered by a lowered dome on spherical plumes, from which two corridors (the other two are not visible in the scene), covered by a barrel vault with lacunar, branch off (Fig. 17).

Lowering the observer's eye to the ground, the Author gives a more dramatic effect to the vaulted roofs represented. We noticed that Ferdinando again refers to an expansion of the painted architectural scene by inserting another portion, on the right side of the façade, which is not present in the plan below, for the benefit of a greater width of the sketch, otherwise unusually shaped for a theatrical setting, that must be a horizontal rectangle to fit in the proscenium and to ensure the spectator the best vision. However, the treatise does not deal with any description on "how" to set, on the stage, the architectural perspective just shown, suddenly moving to the next section regarding theatrical machines. Figure 18 shows one of the most probable disposition of flat panels and backdrop on the stage.

Of great importance for the present study is the drawing at page 132 (Fig. 19) of the treatise, in which the Author explains how to draw an architectural perspective on a painted stage flat, without the need for any plan below the ground line, using only a regular grid, as highlighted by the overlapped grid of Fig. 20. The method was already known by scenographers and consisted of lines passing through the edge of the grid and converging toward the central vanishing point. Each painted flat has its own vanishing point and they are all aligned along the horizontal straight line passing through the center of the projective system, i.e. the privileged observer's eye. Figure 21 illustrates how to fix the vanishing point on each panel and on the backdrop, according to the rules of the treatise. Ferdinando Galli Bibiena introduces 


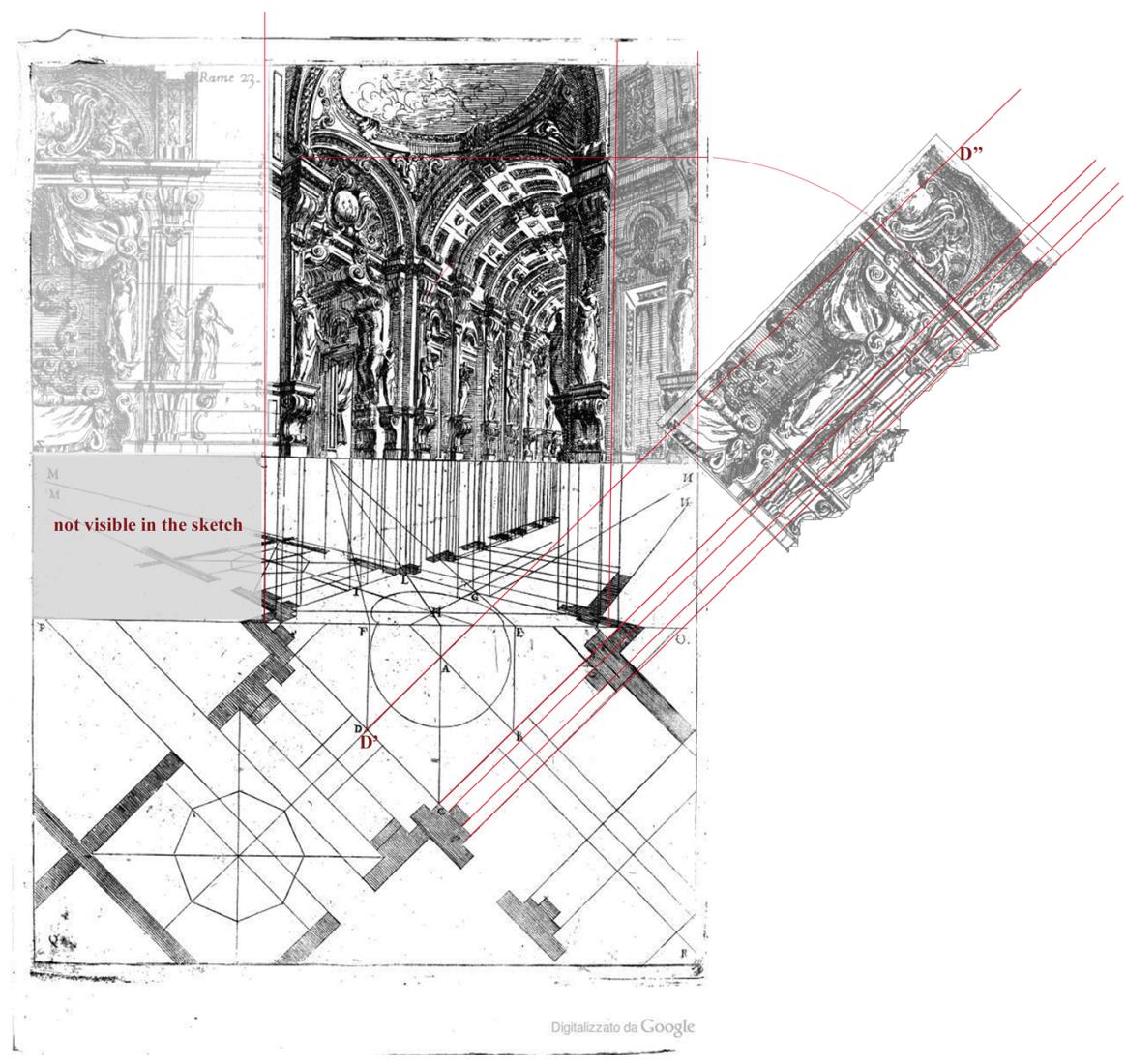

Fig. 17 Geometric processes involved in Bibiena's drawing Per disegnare un'altra Scena d'una Sala, ò Stanza veduta per angolo (Galli Bibiena 1711, p. 137)

an original innovation in the aforementioned graphic process, determining a unique zone in which horizontal lines do not converge, but remain parallel to the ground line and the horizon. This expedient is again in accordance with the need to obtain the perspective plan fully coincident with a segment at the base of the panel, without any representation of its depth. Below the line of horizon, therefore, the bases of the columns will be drawn as orthographic projections, while above the perspective will follow its traditional rules of convergence, driving spectators' eyes towards the richness of details that decorate the painted ceiling and vaults.

The same Author denounces the trick as a derogation of the perspective rules, but justifies its use for the purpose of an improved visibility of the setting, as highlighted in the perspective comparison of Fig. 22, according to a consolidated tradition of several great masters, such as Troili, of whom he was a student (Galli Bibiena 1711, p. 134). Ferdinando explains that the plan of the column basement (correctly drawn in perspective in the detail of the same table) will take place too internally, with respect to the base of the flat (Telaro), and so he suggests adapting 


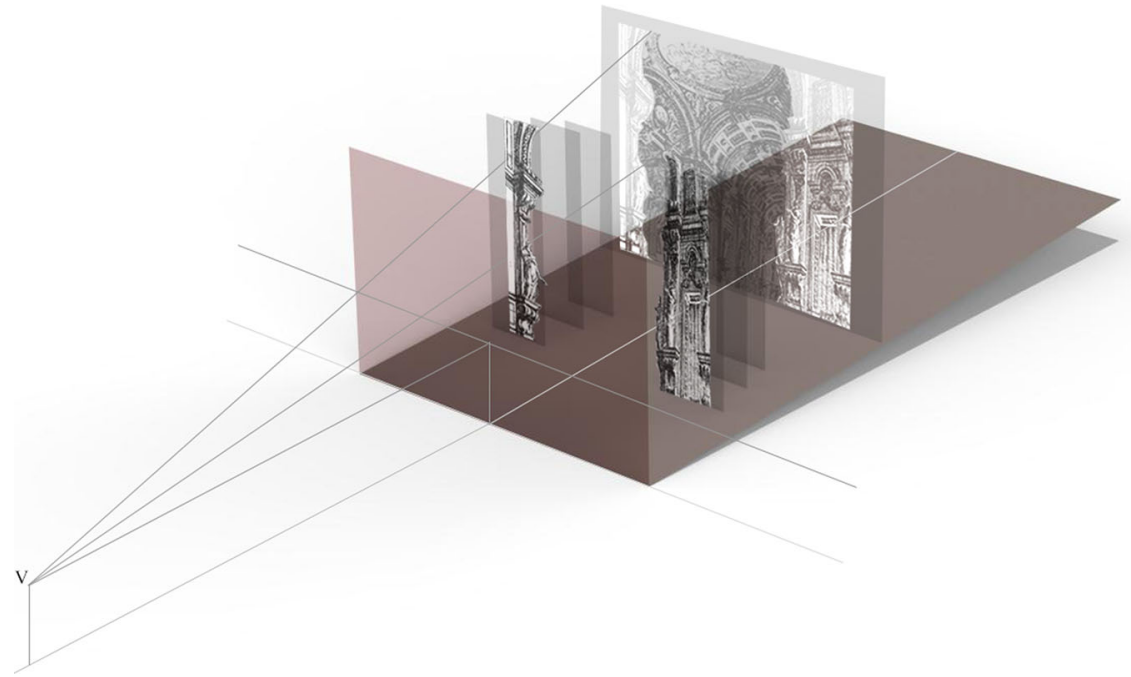

Fig. 18 The image shows one of the most probable stage settings of the previous architectural perspective, according to the traditional layout of flats and backdrop on the stage

the painting to the bi-dimensional panel, according to a method just tested by the author in the many previous stagings (Bibiena 1711, p. 134).

Bibiena ends the treatise with a section dedicated to the mechanics, defined as the art of moving, holding and carrying of weights, in which the Author provides the basic principles for the functioning of levers, scales, pulleys and toothed gears, necessary equipment for the dynamic Baroque scene. Spectacular effects at theatre were, in fact, more and more frequently wanted and stage settings acquired a totally different aspect from the previous Renaissance examples; the need for exciting and frequent changes stimulated the scenographers' imaginations toward finding new mechanisms to facilitate all the speedy replacements required.

Changing seascapes, dark clouds suddenly looming from above, views of city streets, caves and massive rocks are just some of the elements of the Baroque theatre's spectacular nature.

In the subsequent treatise, printed in Bologna in 1753, entitled Direzioni della prospettiva teorica corrispondenti a quelle dell'architettura, and dedicated to the students of the Clementine Academy of Bologna, Ferdinando inserts a new drawing to explain how to stage an architectural perspective of his own invention that he didn't printed, although it was ready, in the 1711 treatise because he was persuaded by a friend to not divulge it. Ferdinando proposes this drawing at the end of his career, without any further changes, indicating that he had not the strength to give more details because of his poor health, which doesn't allow his hand to draw easily (Galli Bibiena 1753, p. 132).

The table shows (Fig. 23) how to set the scene, according to large painted flats which introduce the innovation of setting the panels according to different angles with respect to the proscenium, in order to break uniqueness and fixity of the painted backdrop with three vaulted corridors that increase the effect of depth. 


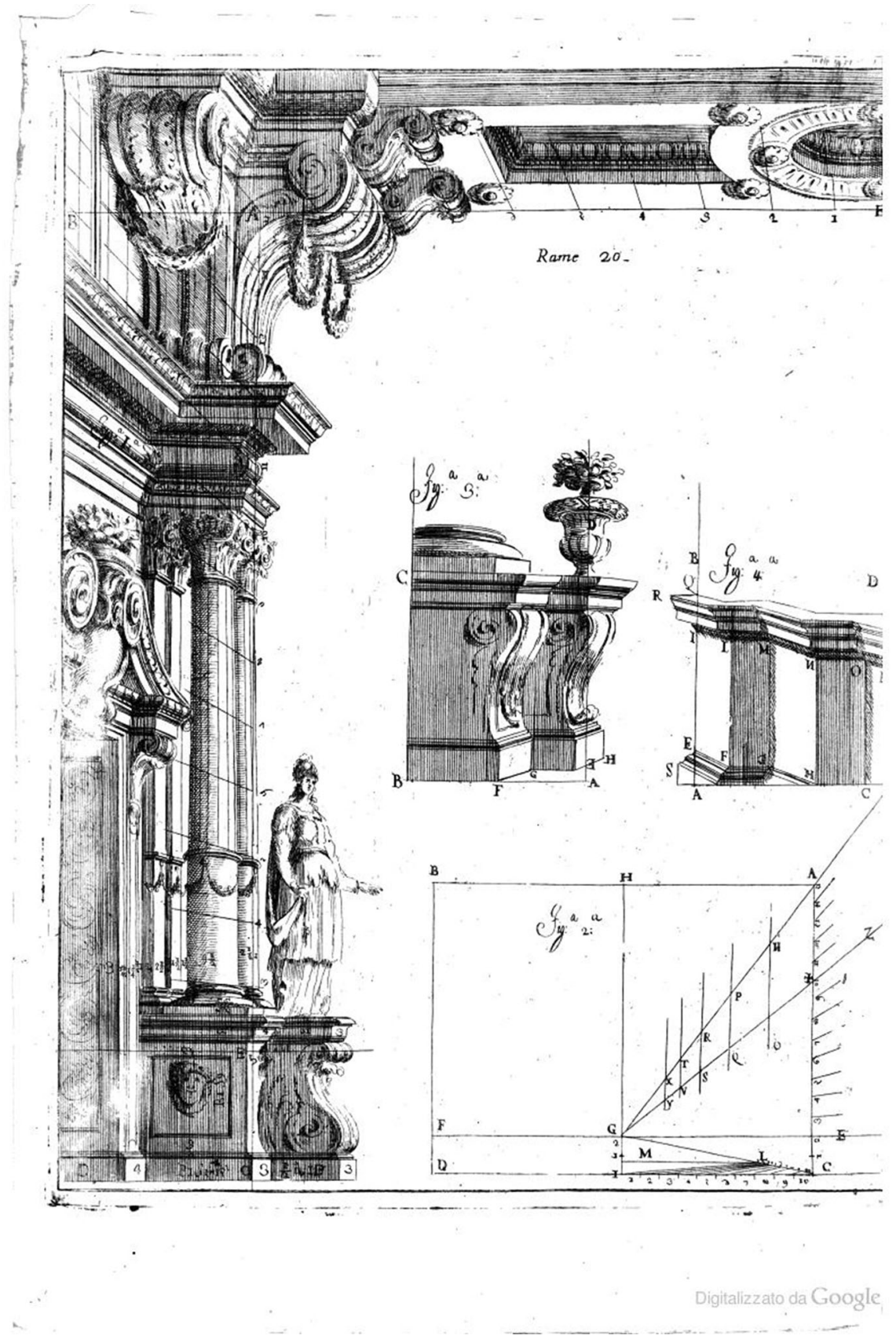

Fig. 19 Ferdinando Galli Bibiena (1711). Per disegnare li Prospetti che abbino corrispondenza colli Telari... (Galli Bibiena 1711, p. 132) 


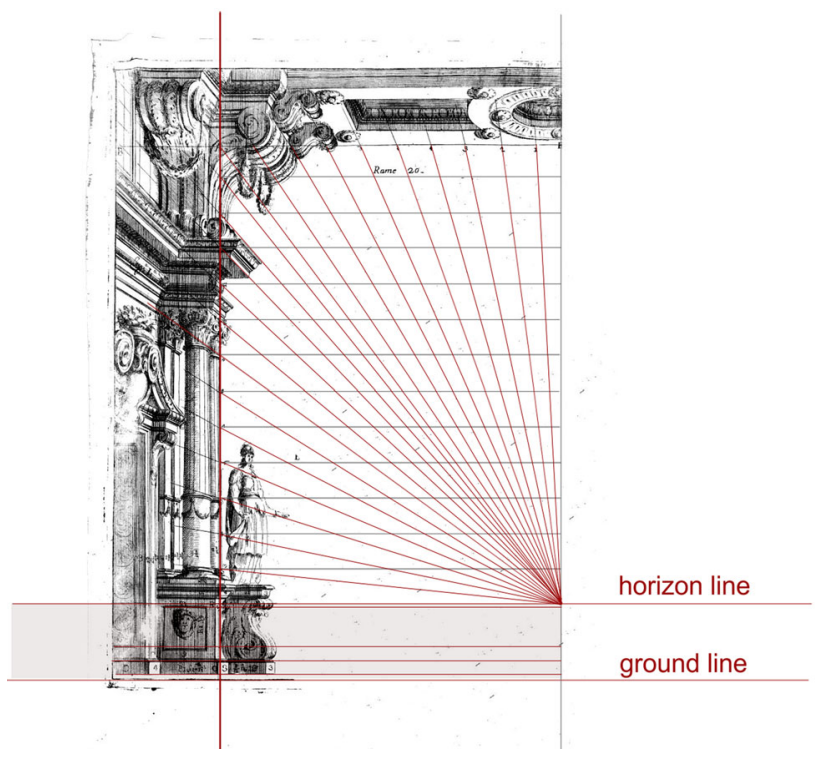

Fig. 20 How to draw architectural perspectives on a stage flat, without the need for any plan below the ground line, using only a regular grid for the correct convergence of the horizontal lines towards the vanishing point of the panel: it's important to note the parallelism of horizontal lines between the horizon and the ground line in order to draw a best fit base for the columns which have to adapt themselves to the flat panel

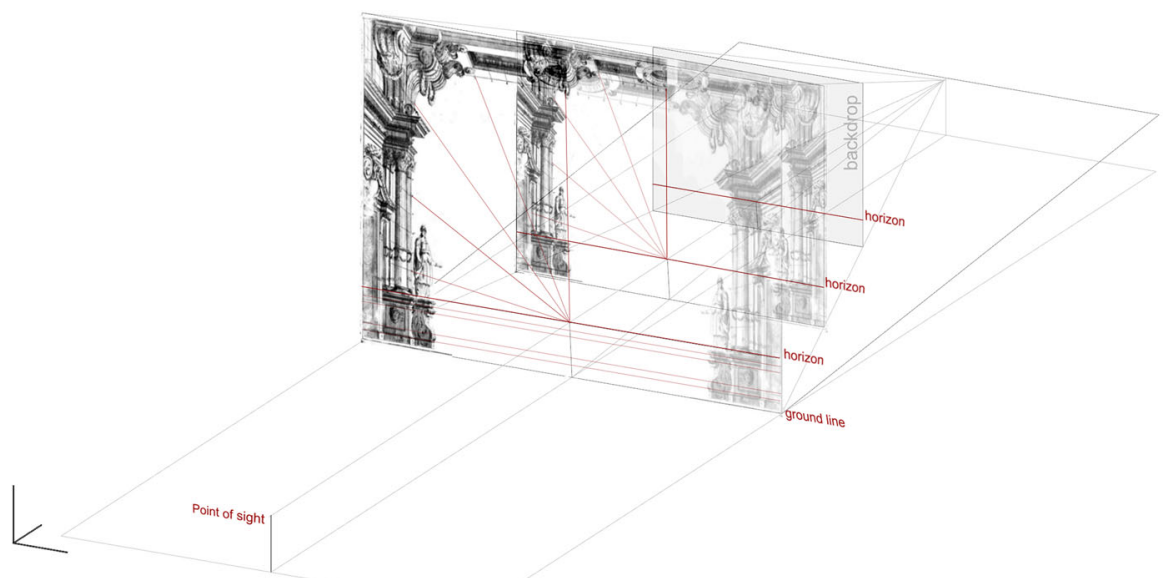

Fig. 21 How to fix the vanishing point on each panel and on the backdrop, according to the rules of the treatise

The Author advises the reader of the importance of being able to design a correct flat layout plan to avoid the loss of the first idea, the sketch, while setting the scene on the stage: 


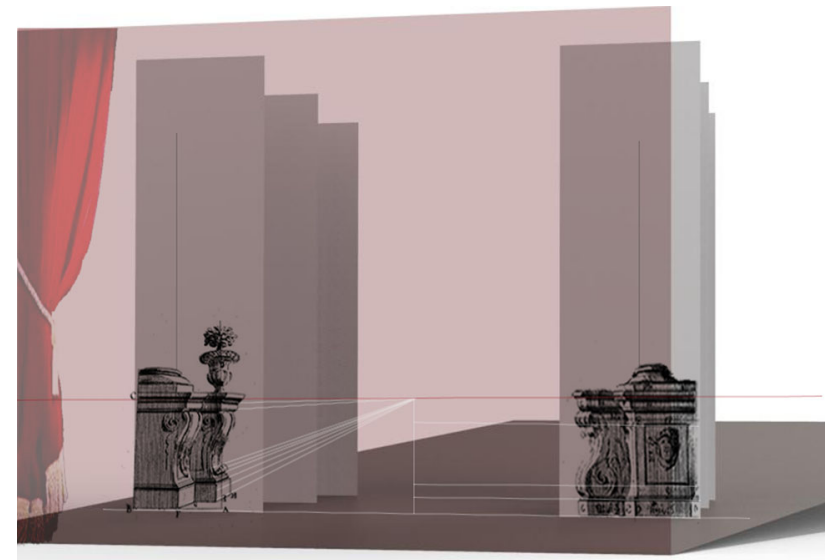

Fig. 22 Comparisons between the two settings proposed by Ferdinando Galli Bibiena: the flat on the right (of the figure) uses a derogation to the general perspective rules to best fit the column bases to the painted panel

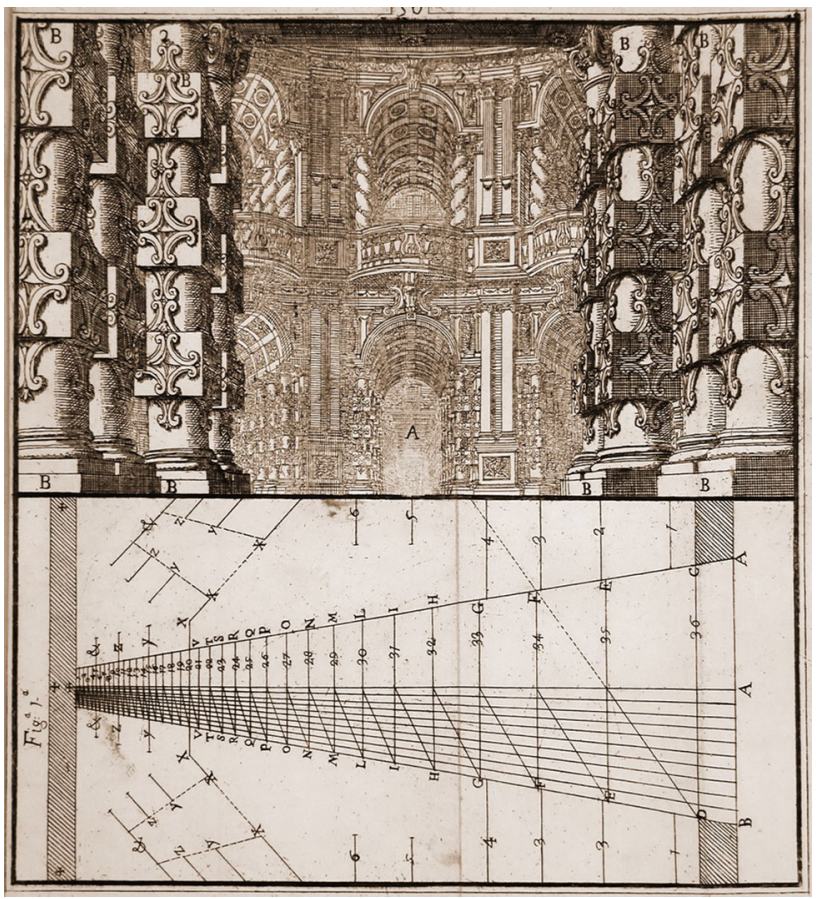

Fig. 23 Ferdinando Galli Bibiena (1753). Altra forma di disegnare le Scene di nuova invenzione, che appariscano grandi a misura di ciò si desidera, Operazione 69, Tav. 50 (Galli Bibiena 1753, p. 105) 
There is no doubt that the greatest difficulty that arises in the inventions of theatrical scenes, as well in other similar perspectives, is the difference between the first idea and the final installation, because it changes so much, that sometimes you do not recognize what was once the idea in the mind, you draw a sketch and it differs from the first concept, then you draw on paper according to the rules of perspective and architecture, but for those rules it differs a lot; then you put in opera and lose more and more the spirit of the first idea [Non v'è dubbio alcuno, che la maggior difficoltà che nasce nelle invenzioni delle Scene Teatrali, ed anche alter prospettive d ital sorte, è quella della differenza dalla prima idea, fino all'ultimo termine di porla in opera, perchè cala tanto, che alle volte non si conosce per quella, che fu in mente formato nell'intelletto l'idea, se ne forma uno schizzo, ò abbozzo, quale assai cala dal primo concetto, poi si disegna in carta secondo le regole della prospettiva, ed architettura, ma per tali soggezioni diminiusce assai; poi si disegna in opra e tanto più va perdendo quello spirit, che fu prima in idea...] (Bibiena 1753, p. 115).

\section{Conclusion}

The treatise of Ferdinando Galli Bibiena (1711), is a unique example of transitional work, placed in the path of a strong scenic Renaissance tradition, from which it takes the theoretical rigour of the narrative structure but determines a turning point for the history of scenography thanks to the invention of a new dynamic and imaginative space called "seen at an angle [veduta per angolo]".

With the intention of being purely practical, aimed at training young stage designers who want to consciously penetrate that field of knowledge, the treatise could be considered as an unfinished work: despite the explicit desire for simplification, declared several times by the same author in the last few chapters dedicated to the stage settings and his best inventions, we have noticed a significant lack of information about practical operations to transpose his innovative perspective image on the physical space of the stage.

It seems that Ferdinando had finished his treatise with a demonstration of "how to draw in perspective" his new monumental architectures "vedute per angolo", certainly outlining a change in the style of the time, which unfortunately was not followed by an appropriate change in the consolidated staging rules, which still appear tied to the centrality of the only vanishing point of the Renaissance scene.

The perspective view invented by Ferdinando places its most suggestive architectural elements right in the centre of the image and the arrangement of the scenes to the flat layout, fully explained by the author in the chapters immediately preceding, relegates the architectural perspective to the far backdrop, on which the painted image will be quite fully contained.

The scene in Fig. 23, published in 1753, in the last edition of the treatise, tries to fill this lack by drawing the layout of the flats, their size and the perspective sequence in plan, according to correct distances the one from the others, but the sketch offers a very different perspective from those defined as "per angolo" in the 
previous book, published in 1771. Though richly decorated, full of perspective views and deep vaulted corridors, the scene seems to take a step back towards the centrality of the Renaissance scene and the symmetry with respect to the central void, but enriched by new baroque elements as decorations, dynamism and illusory depth. It appears almost like a rethinking, after the Author became aware of the impossibility of having his perspective views on several flats that can be hosted only on the large surface of the background. This layout will be adopted and developed by all the following scenographers for more than a century.

\section{References}

Accolti, Pietro. 1625. Lo inganno degl'occhi. Florence.

Barbaro, Daniele. 1556. I dieci libri dell'architettura di M. Vitruvio tradotti et commentati da M. Daniele Barbaro. Venezia.

Benois, Nicola. 1962. Set design for Semiramide, Teatro alla Scala in Milan. http://www.teatroallascala. org/archivio/risultato.aspx?lang=it-IT\&uid=cb54a98a-8030-4e14-8443-01df48516393\&objecttype= base \&pagesize $=9 \&$ page $=1$.

Frigerio, Ezio. 1980. Set design for Le Nozze di Figaro, Teatro alla Scala in Milan.

Galli Bibiena, Ferdinando. 1711. L'architettura civile preparata su la geometria e ridotta alle prospettive, Parma.

Galli Bibiena, Ferdinando. 1753. Direzioni della prospettiva teorica corrispondenti a quelle dell'architettura, Bologna.

Howard, Pamela. 2002. What is Scenography? London: Routledge.

Pagliano, Alessandra. 2002. Il disegno dello spazio scenico. Milan: Hoepli.

Pozzo, Andrea. 1723. Perspectiva pictorum et architectorum. Rome: Antonii de Rubeis

Serlio, Sebastiano. 1545. Il secondo libro di prospettiva. Paris: Jean Barbé.

\footnotetext{
Alessandra Pagliano is a researcher, DiArc_Department of Architecture, University "Federico II" of Naples. Her main interests are the Gnomonic (and the history of sundials), the evaluations of visual impacts in landscape, innovative digital technologies for Cultural Heritage and the illusory applications to art of linear perspective method, such as anamorphosis and stage design. On the lastmentioned research theme she has published Il disegno dello spazio scenico (Hoepli 2002), Le geometrie dell'illusione. Artifici prospettici dello spazio scenico (Fridericiana 2009) and a large number of essays and conference papers.
} 